\title{
Holocene climate variability and cultural dynamics in the Indian subcontinent
}

\author{
${ }^{1}$ Wadia Institute of Himalayan Geology, 33 GMS Road, Uttarakhand (India); *Correspondence author, Email: 2015praveenmishra@gmail.com \\ ${ }^{2}$ Indian Institute of Science Education and Research Mohali, Sector 81, Manauli, Punjab 140306 (India) \\ ${ }^{3}$ Now working at Centre for Climate Change \& Water Research, Suresh Gyan Vihar University, Jagatpura, Jaipur (India) 302025 \\ ${ }^{4}$ Now working at Dr. Strauss Department of Marine Geosciences, Leon H. Charney School of Marine Sciences, University of Haifa, Israel
}

(Received : 31/10/2018; Revised accepted : 20/09/2019)

https://doi.org/10.18814/epiiugs/2020/020036

\section{Introduction}

The agriculture sector contributes approximately 14\% of India's total gross domestic productivity (source: Indian Ministry of Agriculture, 2013-2014). The variability in the monsoonal precipitation has a critical impact on agricultural productivity and thus the economy of the country (Krishna Kumar et al., 2004). The dominant (ca. 75\%) contribution of India's annual rainfall is received from the South-West (SW) monsoon, whereas the North-East (NE) monsoon provide precipitation in southern peninsular India and midlatitude westerlies in the North-West (NW) Himalaya (Fleitmann et al., 2007; Gadgil and Rajeevan, 2008; Govil and Naidu, 2011; An et al., 2012; Sreekala et al., 2012; Mishra et al., 2015; Srivastava et al., 2013; 2017). The interaction of these moisture regimes with various teleconnections (El Niño events, Indian Ocean Dipole or IOD, snow cover and North Atlantic Oscillation or NAO) have resulted in decadal to millennial-scale precipitation variation (Ashok et al., 2001; Singhvi and Kale, 2010; Rajeevan et al., 2012; Prasad et al., 2014).

The climate variability has deleterious effects on human civilization (Madella and Fuller, 2006; Giosan et al., 2012; Kathayat et al., 2017). Several studies have highlighted that the ancient societies were highly vulnerable to abrupt climatic events resulting in population dislocations, urban abandonment, and social stresses that can lead to the collapse of civilizations or cultures (Polyak and Asmerom, 2001; Giosan et al., 2012). Even in the present day, climate change has a significant impact on civilizations as evident from the migration of millions of population from the Middle-East to the western world (Brzoska and Fröhlich, 2016). Understanding of past cultural adaptations to persistent climate change may provide valuable perspectives on possible responses of modern societies to future climate change (DeMenocal, 2001; Singhvi et al., 2010).

From an archaeological perspective, the Holocene (from 11700 yr BP to present; where, yr BP is years before present) is a complex time period that witnessed multiple cultural and adaptive innovations, transitions as well as the rise of several civilizations or complex societies around the world (Gupta et al., 2003; Anderson et al., 2007; Dong et al., 2012; Walker et al., 2012). These events took place through a multitude of dynamic processes combining both indigenous developments and population movements/replacements/admixture across vast regions. This epoch is characterized by beginning of pastoralism, domestication of animals, sedentary human life, beginning of the complex social order, and the rise and fall of various dynasties (Hodell et al., 1995; Fuller and Korisettar, 2004; Madella and Fuller, 2006; Ponton et al., 2012).

\section{Research area}

In the Indian subcontinent, the following cultural transitions are known to have taken place during the Holocene: Mesolithic to Neolithic at $\sim 7000$ BC ( 8950 yr BP), Neolithic to Chalcolithic at $\sim 4000$ BC ( 5950 yr BP), Chalcolithic to Iron Age at $\sim 1500$ BC ( 3450 yr BP) (Misra, 2001). The evidence for discrete cultural identification of post-Neolithic archaeological sites are primarily based on the wheel-made ceramic or pottery assemblages, e.g., Padri Ware, Painted Grey Ware, Black and Red Ware, Ochre Coloured Pottery, and so forth (Figure 1). It is important to note that these various transitions did not happen evenly and comprehensively across the subcontinent but were highly varied across time and space. In some regions, specific phases occur only marginally or are absent altogether and hunter-gatherer-forager (advanced Mesolithic) lifestyles continued into the colonial period ( $19^{\text {th }}$ century), overlapping with the more advanced lifestyles that evolved in different parts of the subcontinent such as the Neolithic and Chalcolithic (see Morrison, 2007; Petraglia and Boivin, 2014). In addition, some lifeways manifested regionally (e.g., Megalithic) and chronologically overlapped with different cultures over time (e.g., Neolithic, Chalcolithic, early Iron Age) without any influence or interaction at the pan-Indian level. Inversely, many sub-regions did not witness key stages in cultural evolution or transitions, such as western and central India where Neolithic evidence is conspicuously absent, for example, in these zones, the Mesolithic phase directly transforms to the Chalcolithic, whereas in northern, eastern and southern India both phases are linked by the Neolithic phase (Figure 1). Indeed, many contemporary tribal groups in eastern and northeastern zones of India still maintain Neolithic-style agricultural practices (e.g., slash-and-burn, shifting cultivation, jhum cultivation) indicating strong patterns of environmental, cultural, technological, behavioral and subsistence continuities (e.g., Rao, 1977). The geographically uneven cultural development across the subcontinent eventually led to the regionalization of specific cultures with marked geographic boundaries, some contemporary with each 


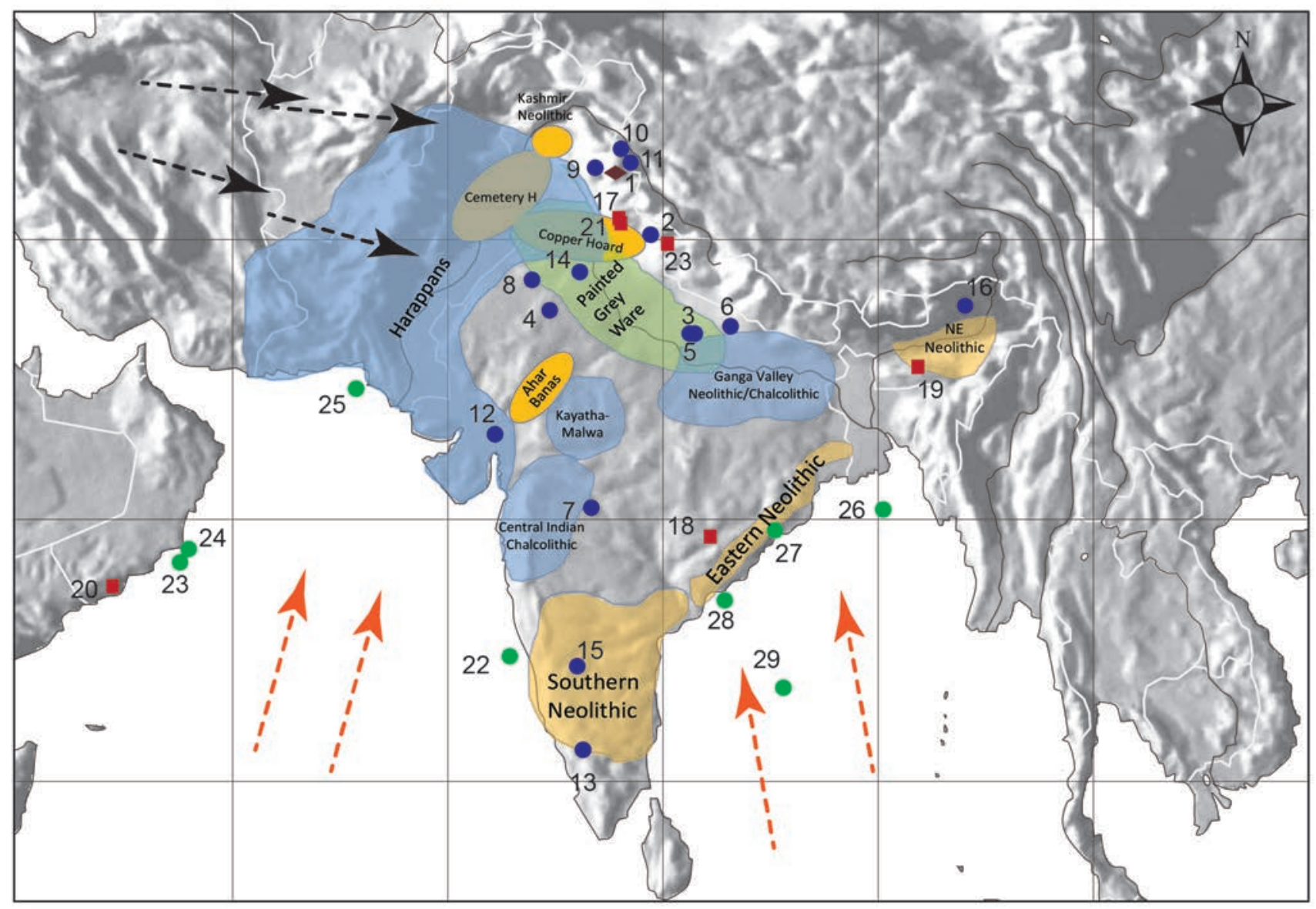

Peat deposits $\bigcirc$ Lake sediments $\square$ Speleothems $\bigcirc$ Marine sediments $=-5$ Mid-latitude westerlies $=->$ South-West monsoon

Figure 1: Major paleoclimatic sites discussed in the text (1. Chandra Tal (Rawat et al., 2015); 2. Benital Lake (Bhushan et al., 2018); 3. Chaudhary ka Tal (Saxena et al., 2015); 4. Dindwana Lake (Wasson et al., 1984); 5. Kikar Tal (Saxena and Trivedi, 2017); 6. Lahuradewa Lake (Saxena et al., 2013); 7. Lonar Lake (Prasad et al., 2014); 8. Lunkaransar (Enzel et al., 1999); 9. Paleolake near Triloknath Glacier (Bali et al., 2016); 10. Tso Kar (Demske et al., 2009); 11. Tso Moriri (Mishra et al., 2015); 12. Nal Sarovar (Prasad et al., 2006); 13. Pookode Lake (Veena et al., 2014); 14. Riwasa paleolake (Dixit et al., 2014); 15. Shantisagara Lake (Sandeep et al., 2017); 16. Ziro basin (Ghosh et al., 2014); 17. Bitto cave (Kathayat et al., 2016); 18. Jhumar cave (Sinha et al., 2011); 19. Mawmluh cave (Berkelhammer et al., 2012$) ; 20$. Qunf cave (Fleitmann et al., 2007); 21. Sahiya cave (Sinha et al., 2015); 22-25. Arabian Sea (Govil and Naidu, 2011; Gupta et al., 2005; Overpeck et al., 1996; Staubwasser and Weiss, 2006); 26-29. Bay of Bengal (Contreras-Rosales et al., 2014; Ankit et al., 2017; Ponton et al., 2012; Rashid et al., 2011) along with different paleo-cultural zones in India.

other. For instance, during the Harappan phase in northwestern India, other contemporary cultures appeared and flourished elsewhere across India, many independently, such as the Ahar, Malwa, Jorwe, the southern Indian Neolithic and others (Misra, 2001; Shinde and SinhaDeshpande, 2002a-b; Singh, 2008) (Figure 1).

\section{Data and Discussion}

In recent decades, there has been a global surge in research on the human-environment relationships during the Holocene, including pinpointing specific factors that affected not only culture change but behavioural responses to environmental fluctuations at different time scales (i.e. annual, centennial or millennial) (Nunn and Britton, 2001; Giosan et al., 2018). Climate change and resulting effects have not only been utilized to explain the demises of specific cultures but also as possible explanations for shifting technological and subsistence strategies. These strategies include selection or preference for specific traits in faunal and floral populations, systematic alteration of local ecologies and planning for long-term exploitation of specific resources about changing environmental conditions (e.g., dam construction, reservoirs, irrigation canals and mining for minerals). From a broad perspective, various cultures in different parts of the world and (within the Indian subcontinent) responded or adapted differently when facing shared environmental conditions or events. These respective strategies depended largely on population sizes, technological levels of the concerned culture, the types and quantities of resources available and social interactions with comparable cultures in surrounding regions.

In the following sections, we have discussed the climate variability in the Indian subcontinent, and the various cultural evolution during the Holocene epoch. We have considered the subdivision of the Holocene as recommended by the working group of Integration of Ice-core, Marine and Terrestrial records (INTIMATE) and International Commission on Stratigraphy (ICS) (Walker et al., 2012; 2018) (Figure 2). 
Age (yr BP)

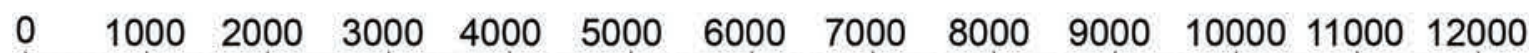

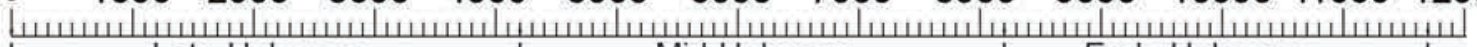
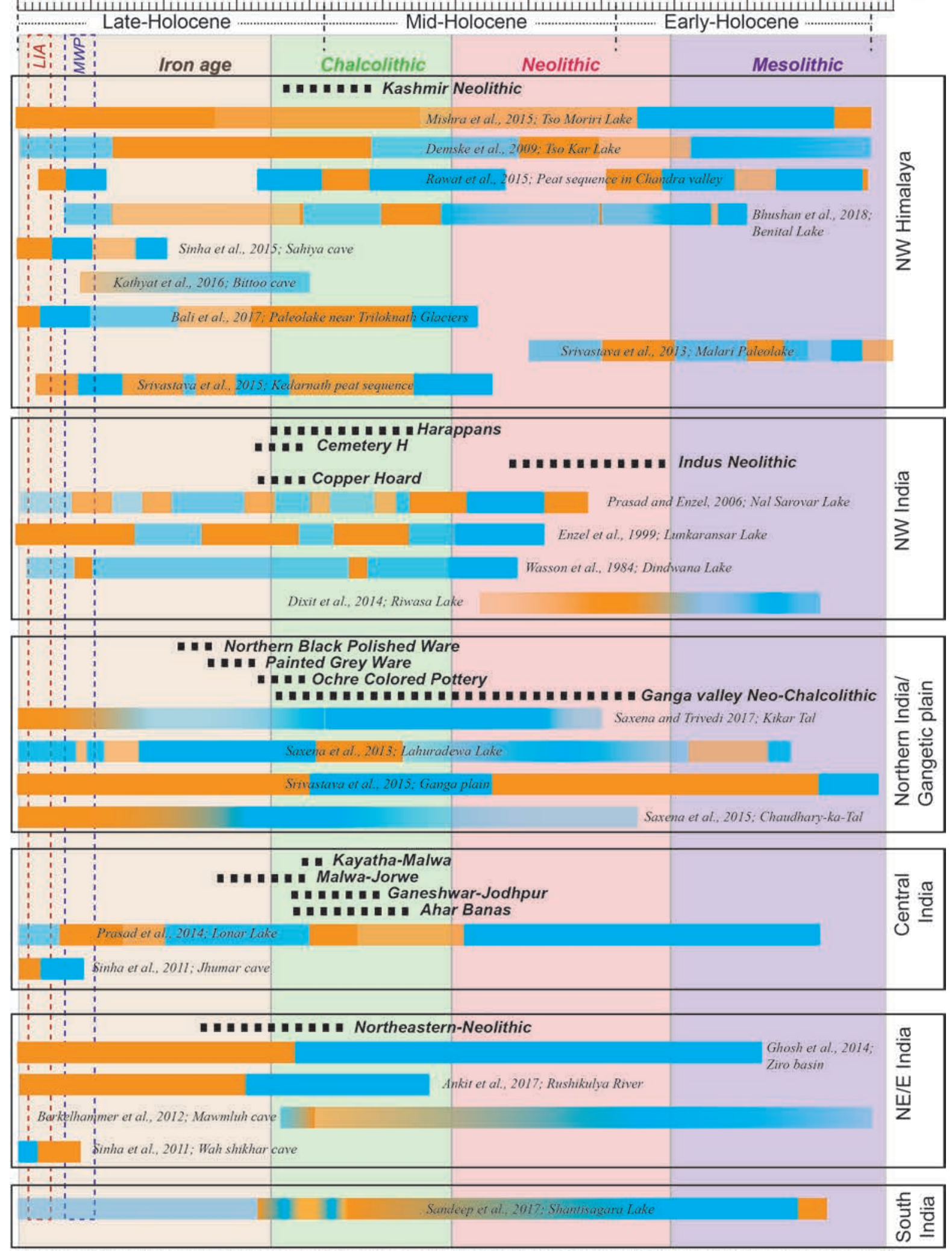

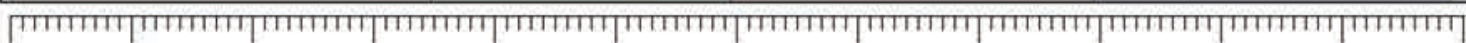

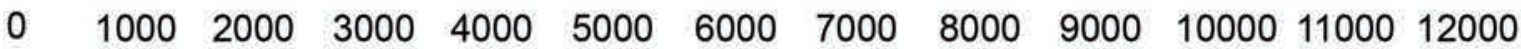 Dry Wet Age (yr BP)}

Figure 2. Paleoclimate variability with major cultural activity in various part of the Indian subcontinent. 


\section{Early Holocene or Greenlandian (11700 to 8200 yr BP)}

The high-resolution Holocene climate records from the Indian subcontinent is mostly available from the NW Himalaya, (the region influenced by both the mid-latitude westerlies and summer monsoon winds), northwestern India and marine sediments from the Indian ocean (Figure 1). However, with a few exceptions, the northeastern Himalaya, peninsular and central India show scarcity in the paleoclimate datasets. The lacustrine records from the central (Lonar Lake) and southern India (Shantisagara Lake) indicate early Holocene climate intensification with initiation of a wet phase at ca. $11 \mathrm{kyr}$ BP (Prasad et al., 2014; Sandeep et al., 2017) (Figure 2). The paleorecord from the Lahuradewa Lake in the Gangetic plain also shows intensified monsoon condition during 9.2 to $5.3 \mathrm{kyr}$ BP with maximum intensity around 7 kyr BP (Saxena et al., 2013) (Figure 2). The presence of Cerealia pollen and occurrence of Trapa and Cannabis sativa around $6 \mathrm{kyr}$ BP indicates human settlements in the region in response to climate amelioration (Saxena et al., 2013). Additionally, based on the geomorphological investigation and variation in clay mineral formation, Srivastava et al., (2015) have observed two humid phases in the Gangetic plains during 13.5 to 11.0 and 6.5 to $4.0 \mathrm{ka}$ (Figure 2). In the Gangetic plain, during the transition phase between early and mid-Holocene, several mature cultural sites have been reported (e.g., Lahuradewa, Senuwar), indicating the close relationship between climate and human activity (Figure 2) (Saxena et al., 2013). Also, the paleoclimate datasets from the northwestern Himalaya demonstrate extreme monsoon precipitation during the early Holocene in response to changes in the solar insolation (Wünnemann et al., 2010; Srivastava et al., 2013; Leipe et al., 2014; Mishra et al., 2015; Rawat et al., 2015; Bhushan et al., 2018) (Figure 2). The fluvial records from the NW Himalayan region corroborates high fluvial incision during the early Holocene with SW monsoon penetrated deep into the orographic barrier of the Himalaya (Bookhagen and Burbank, 2006; Phartiyal et al., 2009). In the northeastern Himalaya, except for studies on instrumental climate data and neotectonism, limited paleoclimate records are available dealing with the dynamics of the monsoon, their causal mechanisms and variability in the moisture source. The paleo-record from the Pasighat region in Arunachal Pradesh shows monsoon intensification between 10 and 8 ka, coeval with other paleo-records from NE India (Srivastava et al., 2009). In contrast, the pollen, phytoliths and stable carbon isotopic investigation from NE Himalayan ranges have provided monsoon intensification between 10.2 and 3.8 kyr BP (Ghosh et al., 2014) (Figure 2). However, this extended period of Holocene intensification does not show any correlation with other paleo-record from NE India and needs more detailed investigations to understand the reasons for its apparently anomalous behavior.

In contrast to the reported early Holocene intensification in the Indian subcontinent, disparity has been observed in the the pollen and geochemical records from the lacustrine sediments in NW India which indicates fluctuating lake levels during the early Holocene and maximum wet condition during 7.2-6 kyr BP (mid-Holocene). The extreme wet condition during the mid-Holocene in the NW India is explained in terms of increased summer rains which also supplemented by high winter rains brought in by the mid-latitude westerlies (Prasad and Enzel 2006 and references therein). The increased westerlies contribution in the NW India supports the dominance of winter crops (e.g., wheat, barley) which is observed in several cultural sites in
NW India (Fuller, 2006; Sarkar et al., 2016). On the contrary, the recent climate records from Riwasa Lake (NW India) shows early Holocene intensification (during 11 to $10.4 \mathrm{kyr} \mathrm{BP}$ ) in response to increased solar insolation and reduced snow cover over the Tibetan Plateau (Marzin and Braconnot, 2009; Dixit et al., 2014) (Figure 2). The cultural record from NW India provides evidence of the beginning of agricultural practices and the domestication of animals during the early Holocene ( 9 kyr BP) (Allchin and Allchin, 1997). Human occupation during the early Holocene in the NW region of the subcontinent is best represented by extensive excavations at Mehrgarh (in modern-day Pakistan). The habitation record at this site (70002000 BC or $\sim 8950$ to 3950 yr BP) is spread across six mounds and starts with the Aceramic (without pottery) Neolithic and reflects early farming and herding practices. It is thought to be a precursor to the subsequent Early Harappan culture and comprises a continuous sequence of eight cultural periods ending with Chalcolithic occupation. Period 1 (7000-5500 BC or $~ 8950$ to 7550 yr BP) comprises evidence of semi-nomadic populations practicing early forms of agriculture and domestication of both fauna and flora. The residential compartmentalized structures were built using mud bricks and a sophisticated material culture is reflected through the presence of burials with intricately made grave goods including ornaments, lithics and bone tools. Comparable early Neolithic evidence, though representing short-term camping, has also been reported recently from the Ladakh Himalaya (Ganjoo, 2015).

The termination of the early Holocene is marked by the global cooling event (known as 8.2 ka event which lasted for at least $\sim 150$ years) reported in several paleoclimate records across the world (Bond et al., 2001; Feng and Hu, 2008; Prasad et al., 2009; Walker et al., 2012). The first global cooling event recorded during the Holocene epoch is marked by fluctuation in the North Atlantic deepwater circulation and northward movement of heat due to the mixing of meltwater from Laurentide ice sheets (Hong et al., 2003; Walker et al., 2012; Marzin et al., 2013; Menzel et al., 2014). Considering dating uncertainty, this event has been reported in several terrestrial (Anoop et al., 2013b; Walker et al., 2012; Dixit et al., 2014; Rawat et al., 2015; Sandeep et al., 2017) as well as marine archives (Gupta et al., 2003; Govil and Naidu, 2011; Rashid et al., 2011). However, no major focused studies have yet been done in India to explicitly link $8.2 \mathrm{ka}$ event with specific cultural adaptations/changes, though this is a time when the Neolithic lifestyle is well-established in some regions and just beginning to appear in other regions of the subcontinent (Figure 1).

In NW India, one of the longest climate-civilization record near to the Indus-Ghaggar-Hakra river valley based on the isotopic and archaeological data suggesting pre-Harappan habitation along the river valley fed by intensified monsoon during 9 to 7 kyr BP (Sarkar et al., 2016). Additionally, the archaeological records across India during this time period show technological advancement. For example, the dominance of Mesolithic tools as represented by microliths made into backed lithics, composite tools including arrowheads and occasional heavy-duty tools such as choppers and core scrapers (Misra, 2001). There is also a discernible increase in the exploitation of perishable materials such as bone, ivory, wood, antler, shell and ostrich eggshells - the latter for beads and engravings. While no climatic factors have yet been explored to explain these morphological shifts in technology, specific tool types and tool-kits must have been innovated and adopted to exploit select resources in differing ecozones. The microlith assemblages are largely comprised of geometric types 
which appear to have been developed from non-geometric microliths (e.g. points, microblades, burins, small flakes, different core types, thumbnail scrapers), the earliest of which occur at $48 \mathrm{ka}$ in Sri Lanka (Wedage et al., 2019). The younger and more advanced geometric microlith types include crescents, lunates, triangles, trapezes, and so forth. These specialized tools are utilized to make composite tools such as arrowheads, knives, harpoons and also supplemented with sophisticated hunting adaptations such as trapping, fishing and so forth, demonstrating the expansion of existing ecological niches. This entire Mesolithic phase is also represented by extensive rock shelter habitation and associated rock art and other complex behaviours such as human burials. Although thousands of Mesolithic sites have been reported from throughout the subcontinent, the best-known examples include Langhnaj in Gujarat, Baghor in Rajasthan, the Ganga Valley complex and Bhimbetka in Madhya Pradesh. While the Neolithic record starts to appear at around 6000 BC ( 7950 yr BP), Mesolithic technology and lifestyle appear to continue well into Historical times overlapping with all subsequent technological and cultural phases.

\section{Middle Holocene or Northgrippian (8200 to 4200 yr BP)}

The majority of paleo-records in the Indian subcontinent is characterized by decreasing monsoonal precipitation during the midHolocene with termination at around $4200 \mathrm{yr}$ BP (also termed as 4.2 ka event) (Staubwasser and Weiss, 2006; Berkelhammer et al., 2012; Walker et al., 2012; Sinha et al., 2015; Kathayat et al., 2017; Sandeep et al., 2017) (Figure 2). The paleoclimate record from the continental Oman (Fleitmann et al., 2007), Arabian Sea (Gupta et al., 2005), Bay of Bengal (Ponton et al., 2012; Contreras-Rosales et al., 2014) and southern India (Sandeep et al., 2017) demonstrated progressively decreasing monsoon intensity during the mid-Holocene in response to solar variability. However, the pollen-based records from the Gangetic plains and paleo-records from NW India show fluctuating precipitation condition, probably due to a variable moisture source and proxy sensitivities (Prasad and Enzel, 2006; Saxena et al., 2013, 2015; Saxena and Trivedi, 2017) (Figure 2). In central India, the $\delta^{18} \mathrm{O}$ record from Kotumsar cave indicates several small periods of enhanced monsoonal precipitation punctuated by a series of megadroughts during the mid-Holocene linked to the weaker North Atlantic circulation (Band et al., 2018) and higher frequency of El Niño events as evident from the El-Junco grains size records (Overpeck et al., 1996; Conroy et al., 2008; Band et al., 2018). Furthermore, in the NW Himalaya, due to the interaction between the Indian Summer Monsoon (ISM) and the westerlies, a complex climate dynamics has been observed in several terrestrial records (Demske et al., 2009; Leipe et al., 2014; Rawat et al., 2015; Bali et al., 2016; Srivastava et al., 2017; Bhushan et al., 2018) (Figure 2). These records show that even in the envelope of the declining phase of monsoon intensity, some of the climate records show a second peak of intensification during the mid-Holocene (Demske et al., 2009; Anoop et al., 2013b) (Figure 2). Similarly, the lake records from NW India show a wetter climate as compared to the early Holocene (Prasad and Enzel, 2006; Staubwasser and Weiss, 2006; Achyuthan et al., 2016). In Didwana Lake, absence of Cosmarium (a freshwater alga) and presence of desert taxa (Calligonum) during ca. 5.8-4.8 kyr BP indicate increased aridity (Singh et al., 1990) which was also corroborated with geochemical data (Wasson et al., 1984) (Figure 2). Contrastingly, the Lunkaransar and Nal Sarovar Lake showed the wettest periods during mid-Holocene (ca. 7.2-6.0 kyr BP and ca. 7.2 to $6.1 \mathrm{kyr}$ BP respectively), probably due to the contribution from winter precipitation (Enzel et al., 1999; Prasad and Enzel, 2006) (Figure 2). However, during 6.1 to 5.3 kyr BP, Nal Sarovar showed a drier period while Lunkaransar remains wet (ca. 6.0-5.3 kyr BP). This discrepancy can be explained in terms of a difference in the rate of evaporation: higher evaporation rate in Nal Sarovar as compared to Lunkaransar (Prasad and Enzel, 2006).

The termination of the middle Holocene (4.2 ka event) is characterised by a global cooling event caused by reduced solar irradiation resulting in atmospheric cooling in northern Hemisphere ( 1-2 ${ }^{\circ} \mathrm{C}$ ), weakening of thermohaline overturning, all of which consequently impacted the intensity of the south-west monsoon precipitation in the Indian subcontinent (Bond et al., 2001; Hong et al., 2003). On the contrary, several studies highlighted a low temperature of north Atlantic surface water, coupled with the increasing frequency of ocean-atmospheric phenomenon (El- Niño events) in the mid-latitude region, have resulted in the decreased intensity of the Asian monsoon during 4.2 ka (Sun, 2000; Barron and Anderson, 2011; Walker et al., 2012). The 4.2 ka event is globally recorded and can be linked to a major drought in several parts of the globe which impedes the growth of various cultures and civilizations e.g., western Tibetan plateau, western Africa, Mexico, the Mesopotamian plains and the Indus Valley region (Yasuda, 2001; Hong et al., 2003). In fact, the cultural destabilization within the Harappan civilization is attributed to the weakening of monsoon precipitation during the mid-Holocene (Singh et al., 1974; Bryson and Swain, 1981; Agrawal et al., 1982; Swain et al., 1983; Petrie et al., 2017). Additionally, the changing pattern of crop production from wet evergreen to deciduous also revealed less moisture availability during the mid-Holocene (Madella and Fuller, 2006). At Bhirrana in NW India, Sarkar et al., (2016) demonstrate (using faunal compositions and oxygen isotopes) a change from monsoondependent to drought-resistant crops, to explain the Harappan decline in the region (also see Singh et al., 2017).

Around the $7^{\text {th }}$ millennium BC ( $\sim 9$ to $\left.7 \mathrm{kyr} \mathrm{BP}\right)$, early signatures of the Neolithic start to appear such as pastoralism, animal domestication and the establishment of simple villages and signifying sedentism. The best-known evidence comes from such sites and regions as Mehrgarh in Pakistan, Kashmir and eastern and northeastern India (Misra, 2001; Singh, 2008). This is also the phase when the earliest (handmade) pottery in the subcontinent appears and is often found in association with bones of both wild and domesticated animal species. The advent of these behaviours, particularly early agriculture, was historically thought to be introduced, but new and older evidence from northern India now suggests a possible indigenous origin. The site of Lahuradewa ( $7^{\text {th }}$ millennium BC) in the Ganga Valley, for example, is showing earlier evidences of possible rice domestication, ceramic use and landscape burning than previously known (see Fuller, 2006). In addition, the gradually developing Neolithic phase subsequently includes increased animal and plant domestication including displacement and alteration of specific species and animal communities (Boivin et al., 2016). The rapid spread of these burgeoning human populations and associated anthropogenic activities (e.g., clearing forests, burning swaths of land, and overhunting) also begin to have major impacts on the local ecologies and biodiversity (Kirch, 2005). The most ubiquitous artefacts or tools of this period are polished axes/celts, directly linked with the widespread deforestation and generally known from all parts of India except 
western and central zones. In fact, this growing impact of human activities on their natural environment (with roots in the Late Pleistocene) subsequently led to a proposal to recognize a new phase called the Anthropocene (Malhi, 2017). The middle Holocene also marks the establishment of the roots of Harappan culture, generally labeled as the pre-Harappan phase followed by the Early Harappan phase (Possehl, 2002). While the pre-Harappan phase (5500-3300 BC or 7450-5250 yr BP) is represented such sites as Mehrgarh (described above), the Early Harappan phase (3300-2800 BC or 52504750 yr BP) often called the Ravi Phase) comprises of the beginning of the use of a script (yet to be deciphered) and establishment of raw material transport and trade including lapis lazuli, steatite and Rohri chert. Soon after 2800 BC (4750 yr BP), the Early Harappan phase transforms into the Mature Harappan phase. This phase (2800-1900 $\mathrm{BC}$ or $4750-3850 \mathrm{yr} \mathrm{BP}$ ) is the height of the culture's prominence and had spread to various parts of Pakistan and NW India (including Gujarat, Rajasthan, Panjab, Haryana, Uttar Pradesh), and Maharashtra (Figure 1). The Mature Harappan phase represented the first urbanization in the subcontinent with several major cities emerging e.g., Harappa, Mohenjo-Daro and Ganweriwala in Pakistan and Dholavira and Rakhigarh in India. Today it is considered to one of the greatest civilizations that appeared throughout the old world and is best known for its standardization in material culture (e.g. city/ town layout, architecture, brick size, stone weights, beads, seals, pottery designs), trade with nearby cultures outside the subcontinent and historically-attempted links Aryans. One of the longest unanswered questions that is researched upon is to identify the precise factor(s) that led to its decline (discussed below). Interestingly, numerous contemporary Mesolithic, Neolithic and Chalcolithic cultures/entities existed in other parts of the subcontinent, without any archaeologically visible interaction with the Harappan populations.

\section{Late Holocene or Meghalayan (4200 yr BP to present)}

There has been a long debate regarding the natural versus anthropogenic factors on climate variability during the late Holocene (Ruddiman et al., 2015). Several lines of evidence suggest that the role of orbital forcing and increasing $\mathrm{CO}_{2}$ concentration (up to 20 ppm since 7000 years) are the key elements in climate variability during the late Holocene (Broecker et al., 1999). However, this concept of natural variability has been objected by a group of scientists which suggest that the increased concentration of $\mathrm{CO}_{2}$ and $\mathrm{CH}_{4}$ and other greenhouse gases, overprinted the natural climate variability and underscored the role of anthropogenic activity in governing the climate condition during the late Holocene (Ruddiman, 2003; Ruddiman et al., 2016).

The late Holocene witnessed a declining phase of monsoon intensity reported from various continental and marine records in the Indian subcontinent attributed to the southern migration of the Intertropical Convergence Zone (ITCZ) coupled with increased frequency of El Niño events (Gupta et al., 2003; Fleitmann et al., 2007; Govil and Naidu, 2011; Ponton et al., 2012; Contreras-Rosales et al., 2014; Ankit et al., 2017) (Figure 2). The Dhakuri peat deposit in the NW Himalaya (Phadtare and Pant, 2006) indicates a weakening of the ISM during 3.2 to $0.2 \mathrm{kyr} \mathrm{BP}$ corroborating with the climate record from the Tibetan peat deposit (Hong et al., 2003; Singhvi and Kale, 2010). The drying trend is also supported by the speleothem record from the NW Himalaya (Sainji cave) indicating a weakening of the SW monsoon from 4.0 to $3.2 \mathrm{kyr}$ BP which accounted for the disappearance of the Ghaggar river and the collapse of the Indus/ Harappan and Ghaggar cultures in northern India (Kotlia et al., 2015). However, using sedimentary paleo-DNA and planktonic foraminifera, Giosan et al., (2018) have identified strong monsoonal activity between ca. 4.5 and 3 kyr BP, which possibly induce a change in Harappan lifeways from urban to rural. Such changes were also demonstrated by sediment and pottery analyses from Kalibangan which collectively showed a transition of the Ghaggar river from being glacial-fed to rain-fed during the Mature Harappan phase (Chatterjee and Ray, 2018). The Mature Phase gives way to the Late Harappan phase (1900-1300 BC or 3850-3250 yr BP) which witnessed the brief existence of the Cemetery $\mathrm{H}$ culture and introduction of Ochre Coloured Pottery. This phase comprised of a gradual decline in trade, settlement size, economy and material culture such as Harappan pottery as well as site abandonment. The multiple urban centres begin to collapse into fragmented rural networks and the earlier defining elements of Harappan culture start to disappear including the use of the script. The end of the Harappan phase was marked by the transition from Bronze to Iron Age and was succeeded by the Painted Grey Ware culture and other contemporary cultures across India including various Megalithic cultures.

In central India, the isotopic data suggested that the period of aridity intensified after $4.0 \mathrm{kyr}$ BP and persisted until $1.7 \mathrm{kyr}$ BP due to a change in the seasonality of northern hemisphere insolation (Ponton et al., 2012). The climate record from Lonar Lake in central India indicates multiple drought events (during 4.6 to 3.9 and 1.4 to 0.6 kyr BP) based on the occurrence of evaporative (gaylussite) minerals (Anoop et al., 2013a; Prasad et al., 2014) (Figure 2). The absence of Gaylussite at 2 kyr BP suggests a relatively wet condition, during which some of the sites in central India (e.g., Bhokardan, Paithan, Ter, Bhon) show well flourished economic and cultural growth (Deotare, 2006; Prasad et al., 2014). These data suggested that there were symbiotic human and climate interaction that persisted at least since last 4000 years. Several cultures in the Indian subcontinent adapted their lifestyles according to drier climatic conditions, e.g. rapid increase in rainwater harvesting structures (after $1.7 \mathrm{ka}$ ) in south India, Harappan settlement shift towards relatively more wetter regions near the foothills of Himalaya or Ganges watershed or adoption of low rainfall crop patterns (Madella and Fuller, 2006; Ponton et al., 2012; Prasad et al., 2014).

The latter phase of the late Holocene is largely characterised by two centennial-scale climate events (Medieval Climate Anomaly (MCA) or Medieval Warm Period (MWP) during AD 900 to 1350 (1050 to 600 yr BP) and Little Ice Age (LIA) between AD 1500 and 1800 (450 to $150 \mathrm{yr} \mathrm{BP}$ ) which have a strong control over the cultural evolution of various civilisations in the Indian subcontinent (Madella and Fuller, 2006; Vollweiler et al., 2006; Giosan et al., 2012; Dixit and Tandon, 2016). This period witnessed the technological and economic transition from the exploitation of copper, tin and bronze to the beginning of the Iron Age coinciding with the second urbanization (Singh, 2008). Although these events are well recorded in several marine as well as terrestrial records, the spatial heterogeneity in the timing and duration of these events suggest the interplay between the varied contribution of moisture source, change in local sea surface temperature and a link with various teleconnections (such as El Niño, NAO) (Dixit and Tandon, 2016; Tiwari et al., 2009, 2011; Banerji et al., 2017). In some of the climatic records from the Indian 
subcontinent, a warm period from $250 \mathrm{BC}$ to AD 400 or 2200 to 1550 yr BP (called the Roman Warm Period (RWP)) is also reported, however its timing and the duration are still debatable (Banerjee et al., 2017; Kathayat et al., 2017). A study based on pollens from Naychhudwari Bog in the NW Himalaya indicated that around 1.3 to 0.75 kyr BP (AD 650 to AD 1200) (equivalent to MWP) a warm and moist condition prevailed in the region and thus was favorable for local agricultural practices (Chauhan, 2006). The record is coeval with other paleoclimate records from the NW Himalaya (Yadava and Ramesh, 2005; Sinha et al., 2011) (Figure 2). Additionally, based on the multiproxy data from mudflat sediments from Diu (western India), Banerji et al., (2017) suggested that the climate in western India was warm and humid during 3.2 and $2.6 \mathrm{kyr}$ BP followed by aridity until $1.9 \mathrm{kyr} \mathrm{BP}$ and further reoccurrence of wet phase from 1.9 to 0.35 kyr BP (AD 50 to AD 1600), which is in line with the global RWP and MWP events. The paleo-record from the Gangetic plains shows a continuous decreasing trend of monsoon intensity punctuated with several small-scale warm periods which correspond to the MWP (Saxena et al., 2015) (Figure 2). However, the climate record from southern India and central India shows contrasting behavior during MWP and LIA with paleo-records from the Gangetic plains. The climate records from southern India (Pookode Lake) and central India (Lonar Lake) show drier conditions during MWP, whereas a warmer and wetter climate is evident during LIA (Prasad et al., 2014; Veena et al., 2014).

Furthermore, tree-ring based hydrological studies provide evidence of past climate variability in terms of change in atmospheric temperature and precipitation condition at the annual to decadal timescale in the Himalaya region during the past millennium (Bhattacharyya and Chaudhary, 2003; Singh and Yadav, 2005; Mann et al., 2012; Borgaonkar et al., 2018). Based on the tree ring dataset, Yadav et al., (2017) have reconstructed the paleohydrological condition in NW Himalaya since AD 1439 (past 576 years) inferring that the NW Himalaya witnessed long-term droughts during the $15^{\text {th }}$ to early $17^{\text {th }}$ centuries, followed by the wettest period between 1984 and 2014. In another study from NE Himalaya, Bhattacharyya and Chaudhary (2003) reconstructed decadal scale fluctuation since AD 1507 and found that the periods between 1801 and 1810 were the coolest decades $\left(-0.31^{\circ} \mathrm{C}\right)$, whereas the period between 1978 and 1987 was the warmest $\left(+0.25^{\circ} \mathrm{C}\right)$.

Available paleoenvironmental data from the Late Holocene is not abundant enough to link specific events with cultural change across the subcontinent. While global events (e.g., aridification) have been identified and used to explain the decline of the Harappan civilization, it does not explain or demonstrates how other contemporary cultures (Mesolithic, Neolithic and Chalcolithic) appear to thrive and survive changing environments at different locations. For example, the late Holocene is marked by (comparatively late) transitions in southern India from the Mesolithic to the Neolithic, factors which are not fully known but point to multiple processes leading to an indigenous agropastoral expression (Boivin et al., 2008). The Middle and Late Holocene also witnessed a pan-Indian amalgamation of several different populations with various cultures, technologies, subsistence strategies and ecological adaptations. This critically affects how we identify, classify and interpret such mixed records, and requires great caution as many sites show complicated patterns of interactions between hunter-gatherers, foragers, pastoralists, farmers and traders throughout the entire Holocene (Morrison, 2007). Regarding the decline of the Harappan civilization, recent work suggests that urban settlements were thriving along a part of the Ghaggar-Hakra tract where a major Himalayan river - the Sutlej - had shifted its course much earlier, thus ruling out a causal link between perennial rivers and human settlements.

\section{Conclusions}

Attempting to understand the link between Holocene environmental change and cultural transitions in India has long been hampered by various factors such as research bias, lack of preserved scientific evidence, problematic chronometric data and the lack of multidisciplinary methods at select archaeological sites. For example, while Harappan sites and associated evidence continue to receive steady funding and scientific attention, contemporary Chalcolithic cultures in other parts of India remain poorly known. Critical broad questions that still need to be addressed include: Which geographic, temporal and cultural gaps need to be filled? How can we recognize or pinpoint specific environmental factors as discrete causes of culture change in Indian archaeology? Did pastoralism/early agriculture/ animal domestication develop indigenously in the subcontinent or were these behaviors introduced at different times by incoming groups? Why are the Neolithic phase and material culture (e.g., rock engravings, polished axes) absent from large parts of the subcontinent? How did various cultures respond or adapt to extreme events such as droughts? How did Megalithic cultures appear and spread throughout the subcontinent? Which factor played a greater role in the extinction of specific faunal species (climate change or human behavior)?

From a broad perspective, it may not be productive to seek a single dominating factor that affected a significant change in or demise of an entire culture or civilization (e.g., Mesolithic, Harappan) (e.g., Singh et al., 2017). Different factors must have affected different types of populations in a geographically variable manner, especially considering the large geographic boundaries of some entities such as the Harappan civilization (see Sarkar et al., 2016; Petrie et al., 2017). For instance, the factors that led to the decline of the Sorath Harappans in Gujarat may have been different for their decline in the Punjab/ Haryana region, given the ecological, climatic and adaptive diversity across the entire Harappan domain. The same probably applies to contemporary and subsequent cultural groups including those leading Mesolithic, Neolithic, Chalcolithic, Megalithic and/or Early Historic lifestyles and subsistence strategies. What is required is a series of projects targeting well-known archaeological sites and diverse proxies from associated contexts for accurate and high-resolution paleoenvironmental reconstructions. Archaeologists, geologists and ecologists can work together to address and fill key geographic, chronological and cultural gaps in our knowledge of the past.

\section{References}

Achyuthan, H., A. Farooqui, V. Gopal, B. Phartiyal, and Lone, A., 2016, Late quaternary to holocene southwest monsoon reconstruction: A review based on Lake and Wetland Systems (Studies Carried Out during 2011-2016). Proceedings of the Indian National Science Academy, v. 82, no. 3, pp. 847-868.

Agrawal, D.P., and Sood, R.K., 1982, Ecological factors and the Harappan Civilisation. In: Possehl, G.L. (Ed.), Harappan Civilization, a Contemporary Perspective. Aris \& Phillips Ltd., Warminster, pp. 223-231. 
Allchin, B., and Allchin, R., 1997, Origins of a Civilization, The Prehistoric and Early Archaeology of South Asia, Penguin Books, New Delhi, pp. 287.

An, Z., Colman, S.M., Zhou, W., Li, X., Brown, E.T., Jull, a J.T., Cai, Y., Huang, Y., Lu, X., Chang, H., Song, Y., Sun, Y., Xu, H., Liu, W., Jin, Z., Liu, X., Cheng, P., Liu, Y., Ai, L., Li, X., Liu, X., Yan, L., Shi, Z., Wang, X., Wu, F., Qiang, X., Dong, J., Lu, F., and $\mathrm{Xu}, \mathrm{X} ., 2$ 2012, Interplay between the Westerlies and Asian monsoon recorded in Lake Qinghai sediments since $32 \mathrm{ka}$. Scientific reports, v. 2, pp. 619.

Anderson, D.G., Maasch, K.A., Sandweiss, D.H., and Mayewski, P.A., 2007, Climate and culture change: exploring Holocene transitions. In: Climate Change and Cultural Dynamics pp. 1-23.

Ankit, Y., Kumar, P., Anoop, A., Mishra, P.K., and Varghese, S., 2017, Mid-late Holocene climate variability in the Indian monsoon: Evidence from continental shelf sediments adjacent to Rushikulya river, eastern India. Quaternary International, v. 443, pp. 155163.

Anoop, A., Prasad, S., Plessen, B., Basavaiah, N., Gaye, B., Naumann, R., Menzel, P., Weise, S., and Brauer, A., 2013a, Palaeoenvironmental implications of evaporative gaylussite crystals from Lonar Lake, central India. Journal of Quaternary Science, v. 28, pp. 349-359.

Anoop, A., Prasad, S., Krishnan, R., Naumann, R. and Dulski, P., 2013b, Intensified monsoon and spatiotemporal changes in precipitation patterns in the NW Himalaya during the early-mid Holocene. Quaternary international, v. 313, pp.74-84.

Ashok, K., Guan, Z., and Yamagata, T., 2001, Impact of the Indian Ocean Dipole on the Relationship between the Indian Monsoon Rainfall and ENSO. Geophysical Research Letters, v. 28, no. 23, pp. 4499-4502.

Bali, R., Chauhan, M.S., Mishra, A.K., Ali, S.N., Tomar, A., Khan, I., Sen, D., and Srivastava, P., 2016, Vegetation and climate change in the temperate-subalpine belt of Himachal Pradesh since 6300 cal. yrs. BP, inferred from pollen evidence of Triloknath palaeolake. Quat. Int., v. 444, pp. 1-13. doi:10.1016/j.quaint. 2016.07.057

Band, S., Yadava, M.G., Lone, M.A., Shen, C.C., Sree, K., and Ramesh, R., 2018, High-resolution mid-Holocene Indian Summer Monsoon recorded in a stalagmite from the Kotumsar Cave, Central India. Quaternary International, v. 479, pp. 19-24.

Banerji, U.S., Bhushan, R., and Jull, A.J.T., 2017, Mid” late Holocene monsoonal records from the partially active mudflat of Diu Island, southern Saurashtra, Gujarat, western India. Quaternary International, v. 443, pp. 200-210.

Barron, J.A., and Anderson, L., 2011, Enhanced Late Holocene ENSO/ PDO expression along the margins of the eastern North Pacific. Quaternary International, v. 235, pp. 3-12.

Berkelhammer, M., Sinha, A., Stott, L., Cheng, H., Pausata, F.S., and Yoshimura, K., 2012, An abrupt shift in the Indian monsoon 4000 years ago. Geophys. Monogr. Ser, v. 198, pp. 75-87.

Bhattacharyya, A., and Chaudhary, V., 2003, Late-summer temperature reconstruction of the eastern Himalayan region based on treering data of Abies densa. Arctic, Antarctic, and Alpine Research, v. 35, pp. 196-202.

Bhushan, R., Sati, S.P., Rana, N., Shukla, A.D., Mazumdar, A.S., and Juyal, N., 2018, High-resolution millennial and centennial scale Holocene monsoon variability in the Higher Central Himalayas. Palaeogeography, Palaeoclimatology, Palaeoecology, v. 489, pp. 95-104.

Boivin, N., Fuller, D., Korisettar, R., and Petraglia, M.D., 2008, First farmers in south India: The role of internal processes and external influences in the emergence of the earliest settled societies. Pragdhara, v. 18, pp. $179-200$.
Boivin, N.L., Zeder, M.A., Fuller, D.Q., Crowther, A., Larson, G., Erlandson, J.M., Denham, T., and Petraglia, M.D., 2016, Ecological consequences of human niche construction: Examining long-term anthropogenic shaping of global species distributions. Proceedings of the National Academy of Sciences, v. 113, pp. 6388-6396.

Bond, G., Kromer, B., Beer, J., Muscheler, R., Evans, M.N., Showers, W., Hoffmann, S., Lotti-Bond, R., Hajdas, I., and Bonani, G., 2001, Persistent solar influence on North Atlantic climate during the Holocene. Science, v. 294, pp. 2130-2136.

Bookhagen, B., and Burbank, D.W., 2006, Topography, relief, and TRMM derived rainfall variations along the Himalaya. Geophysical Research Letters, v. 33, pp. L08405.

Borgaonkar, H.P., Gandhi, N., Ram, S., and Krishnan, R., 2018, Treering reconstruction of late summer temperatures in northern Sikkim (eastern Himalayas). Palaeogeography, Palaeoclimatology, Palaeoecology, v. 504, pp. 125-135.

Broecker, W.S., Clark, E., McCorkle, D.C., Peng, T.H., Hajdas, I., and Bonani, G., 1999, Evidence for a reduction in the carbonate ion content of the deep sea during the course of the Holocene. Paleoceanography, v. 14, pp. 744-752.

Bryson, R.A., and Swain, A.M., 1981, Holocene variations of monsoon rainfall in Rajasthan. Quaternary Research, v. 16, pp. 135-145.

Brzoska, M., and Fröhlich, C., 2016, Climate change, migration and violent conflict: vulnerabilities, pathways and adaptation strategies. Migration and Development, v. 5, pp. 190-210.

Chatterjee, A., and Ray, J.S., 2018, Geochemistry of Harappan potteries from Kalibangan and sediments in the Ghaggar River: Clues for a dying river. Geoscience Frontiers, v. 9, pp. 12031211.

Chauhan, M.S., 2006, Late Holocene vegetation and climate change in the alpine belt of Himachal Pradesh. Current Science, v. 91, pp. 1562-1567.

Conroy, J.L., Overpeck, J.T., Cole, J.E., Shanahan, T.M., and SteinitzKannan, M., 2008, Holocene changes in eastern tropical Pacific climate inferred from a Galápagos lake sediment record. Quaternary Science Reviews, v. 27, pp. 1166-1180.

Contreras-Rosales, L.A., Jennerjahn, T., Tharammal, T., Meyer, V., Lückge, A., Paul, A., and Schefuß, E., 2014. Evolution of the Indian Summer Monsoon and terrestrial vegetation in the Bengal region during the past $18 \mathrm{ka}$. Quaternary Science Reviews, v. 102, pp. 133-148.

DeMenocal, P.B., 2001, Cultural responses to climate change during the late Holocene. Science, v. 292, pp.667-673.

Demske, D., Tarasov, P.E., Wünnemann, B., and Riedel, F., 2009, Late glacial and Holocene vegetation, Indian monsoon and westerly circulation in the Trans-Himalaya recorded in the lacustrine pollen sequence from Tso Kar, Ladakh, NW India. Palaeogeography, Palaeoclimatology, Palaeoecology, v. 279, pp. 172-185.

Deotare, B.C., 2006, Late Holocene Climatic Change: Archaeological Evidence from Purna Basin, Maharashtra. Journal Geological Society of India, v. 68, pp. 517-526.

Dixit, Y., Hodell, D.A., Sinha, R., and Petrie, C.A., 2014, Abrupt weakening of the Indian summer monsoon at 8.2 kyr BP. Earth and Planetary Science Letters, v. 391, pp. 16-23.

Dixit, Y., and Tandon, S.K., 2016, Hydroclimatic variability on the Indian subcontinent in the past millennium: review and assessment. Earth-Science Reviews, v. 161, pp. 1-15.

Dong, G., Jia, X., An, C., Chen, F., Zhao, Y., Tao, S., and Ma, M., 2012, Mid-Holocene climate change and its effect on prehistoric cultural evolution in eastern Qinghai Province, China. Quaternary Research, v. 77, pp. 23-30. 
Enzel, Y., Ely, L.L., Mishra, S., Ramesh, R., Amit, R., Lazar, B., Rajaguru, S.N., Baker, V.R., and Sandler, A., 1999, Highresolution Holocene environmental changes in the Thar Desert, northwestern India. Science, v. 284, pp. 125-128.

Feng, S., and Hu, Q., 2008, How the North Atlantic Multidecadal Oscillation may have influenced the Indian summer monsoon during the past two millennia. Geophysical Research Letters, v. 35, pp. L01707.

Fleitmann, D., Burns, S.J., Mangini, A., Mudelsee, M., Kramers, J., Villa, I., Neff, U., Al-Subbary, A.A., Buettner, A., Hippler, D., and Matter, A., 2007, Holocene ITCZ and Indian monsoon dynamics recorded in stalagmites from Oman and Yemen (Socotra). Quaternary Science Reviews, v. 26, pp. 170-188.

Fuller, D. and Korisettar, R., 2004, The vegetational context of early agriculture in South India. Man and Environment, v. 29, pp. 727.

Fuller, D.Q. 2006, Agricultural Origins and Frontiers in South Asia: A Working Synthesis. Journal of World Prehistory, v. 20, pp. 186.

Ganjoo, R. K., 2015, Early Human Adaptation vis-à-vis High Himalayan Landscape and Climate: Ladakh Himalaya, Jammu and Kashmir. Journal of Indian Geomorphology, v. 3, pp. 5-9.

Gadgil, S., and Rajeevan, M., 2008, The Indian monsoon: 4. Links to Cloud Systems over the Tropical Oceans. Resonance, v. 13, pp. 218-235.

Ghosh, R., Paruya, D.K., Khan, M.A., Chakraborty, S., Sarkar, A., and Bera, S., 2014, Late Quaternary climate variability and vegetation response in Ziro Lake Basin, Eastern Himalaya: A multiproxy approach. Quaternary International, v. 325, pp. 1329.

Giosan, L., Clift, P.D., Macklin, M.G., Fuller, D.Q., Constantinescu, S., Durcan, J.A., Stevens, T., Duller, G.A., Tabrez, A.R., Gangal, K., and Adhikari, R., 2012, Fluvial landscapes of the Harappan civilization. Proceedings of the National Academy of Sciences, v. 109, pp. E1688-E1694.

Giosan, L., Orsi, W.D., Coolen, M., Wuchter, C., Dunlea, A.G., Thirumalai, K., Munoz, S.E., Clift, P.D., Donnelly, J.P., Galy, V., and Fuller, D., 2018, Neoglacial Climate Anomalies and the Harappan Metamorphosis. Climate of the Past, v. 14, pp. 16691686.

Govil, P., and Naidu, P.D., 2011, Variations of Indian monsoon precipitation during the last $32 \mathrm{kyr}$ reflected in the surface hydrography of the Western Bay of Bengal. Quaternary Science Reviews, v. 30, pp. 3871-3879.

Gupta, A.K., Anderson, D.M., and Overpeck, J.T., 2003, Abrupt changes in the Asian southwest monsoon during the Holocene and their links to the North Atlantic Ocean. Nature, v. 421, pp. 354.

Gupta, A.K., Das, M., and Anderson, D.M., 2005, Solar influence on the Indian summer monsoon during the Holocene. Geophysical Research Letters, v. 32, pp. L17703.

Hodell, D.A., Curtis, J.H., and Brenner, M., 1995, Possible role of climate in the collapse of Classic Maya civilization. Nature, v. 375, pp. 391.

Hong, Y.T., Hong, B., Lin, Q.H., Zhu, Y.X., Shibata, Y., Hirota, M., Uchida, M., Leng, X.T., Jiang, H.B., Xu, H., and Wang, H., 2003, Correlation between Indian Ocean summer monsoon and North Atlantic climate during the Holocene. Earth and Planetary Science Letters, v. 211, pp. 371-380.

Kathayat, G., Cheng, H., Sinha, A., Yi, L., Li, X., Zhang, H., Li, H., Ning, Y., and Edwards, R.L., 2017, The Indian monsoon variability and civilization changes in the Indian subcontinent. Science advances, v. 3, pp. 1-9.

Kirch, P.V., 2005, Archaeology and global change: The Holocene record. Annual Review of Environment and Resources, v. 30, pp. 409-440.

Kotlia, B.S., Singh, A.K., Joshi, L.M., and Dhaila, B.S., 2015, Precipitation variability in the Indian Central Himalaya during last ca. 4,000 years inferred from a speleothem record: Impact of Indian Summer Monsoon (ISM) and Westerlies. Quaternary International, v. 371, pp. 244-253.

Krishna Kumar, K., Rupa Kumar, K., Ashrit, R.G., Deshpande, N.R., and Hansen, J.W., 2004, Climate impacts on Indian agriculture. International Journal of Climatology. A Journal of the Royal Meteorological Society, v. 24, pp. 1375-1393.

Leipe, C., Demske, D., Tarasov, P.E., and Members, H.P., 2014, A Holocene pollen record from the northwestern Himalayan lake Tso Moriri: implications for palaeoclimatic and archaeological research. Quaternary International, v. 348, pp. 93-112.

Madella, M., and Fuller, D.Q., 2006, Palaeoecology and the Harappan Civilisation of South Asia: a reconsideration. Quaternary Science Reviews, v. 25, pp. 1283-1301.

Malhi, Y., 2017, The Concept of the Anthropocene. Annual Review of Environment and Resources, v. 42, pp. 77-104.

Mann, M.E., Fuentes, J.D. and Rutherford, S., 2012, Underestimation of volcanic cooling in tree-ring-based reconstructions of hemispheric temperatures. Nature Geoscience, v. 5, pp. 202.

Marzin, C., and Braconnot, P., 2009, Variations of Indian and African monsoons induced by insolation changes at 6 and $9.5 \mathrm{kyr}$ BP. Climate dynamics, v. 33, pp. 215-231.

Marzin, C., Kallel, N., Kageyama, M., Duplessy, J.C., and Braconnot, P., 2013, Glacial fluctuations of the Indian monsoon and their relationship with North Atlantic climate: new data and modelling experiments. Climate of the Past, v. 9, pp. 2135-2151.

Menzel, P., Gaye, B., Mishra, P.K., Anoop, A., Basavaiah, N., Marwan, N., Plessen, B., Prasad, S., Riedel, N., Stebich, M., and Wiesner, M.G., 2014, Linking Holocene drying trends from Lonar Lake in monsoonal central India to North Atlantic cooling events. Palaeogeography, palaeoclimatology, palaeoecology, v. 410, pp. 164-178.

Mishra, S., Chauhan, N., and Singhvi, A.K., 2013, Continuity of microblade technology in the Indian Subcontinent since $45 \mathrm{ka}$ : implications for the dispersal of modern humans. PLoS One, v. 8, pp. 69280.

Mishra, P.K., Anoop, A., Schettler, G., Prasad, S., Jehangir, A., Menzel, P., Naumann, R., Yousuf, A.R., Basavaiah, N., Deenadayalan, K., and Wiesner, M.G., 2015, Reconstructed late Quaternary hydrological changes from Lake Tso Moriri, NW Himalaya. Quaternary International, v. 371, pp. 76-86.

Misra, V.N., 2001, Prehistoric human colonization of India. Journal of Biosciences, v. 26, pp. 491-531.

Morrison, K.D., 2007, Foragers and forager-traders in South Asian worlds: Some thoughts from the last 10,000 years. In Petraglia, M.D., and Allchin, B. (eds.), The Evolution and History of Human Populations in South Asia, pp. 321-339.

Nunn, P. D., and Britton, J. M. R., 2001, Human-Environment Relationships in the Pacific Islands around A.D. 1300, Environment and History. The White Horse Press, Cambridge, UK, v. 7, pp. 3-22.

Overpeck, J., Anderson, D., Trumbore, S., and Prell, W., 1996, The southwest Indian Monsoon over the last 18000 years. Clim. Dyn. v. 12, pp. 213-225. doi:10.1007/BF00211619

Petraglia, M.D. and Boivin, N., 2014, Homo sapiens societies: Southern Asia. In: Cummings, V., Jordan, P., and Zvelebil, M., The Oxford handbook of the archaeology and anthropology of hunter-gatherers. Oxford Univ. Press, pp. 328-345.

Petrie, C.A., Singh, R.N., Bates, J., Dixit, Y., French, C.A., Hodell, D.A., Jones, P.J., Lancelotti, C., Lynam, F., Neogi, S., and Pandey, 
A.K., 2017, Adaptation to variable environments, resilience to climate change: investigating land, water and settlement in indus northwest India. Current Anthropology, v. 58.

Phadtare, N.R., and Pant, R.K., 2006, A century-scale pollen record of vegetation and climate history during the past 3500 years in the Pinder Valley, Kumaon Higher Himalaya, India. JournalGeological Society of India, v. 68, pp. 495.

Phartiyal, B., Sharma, A., Srivastava, P., and Ray, Y., 2009, Chronology of relict lake deposits in the Spiti River, NW Trans Himalaya: Implications to Late Pleistocene-Holocene climatetectonic perturbations. Geomorphology, v. 108, pp. 264-272.

Polyak, V.J., and Asmerom, Y., 2001, Late Holocene climate and cultural changes in the southwestern United States. Science, v. 294, pp. 148-151.

Ponton, C., Giosan, L., Eglinton, T.I., Fuller, D.Q., Johnson, J.E., Kumar, P., and Collett, T.S., 2012, Holocene aridification of India. Geophysical Research Letters, v. 39, pp. 1-6.

Possehl, G.L., 2002, The Indus Civilization: A Contemporary Perspective. Oxford. Rowman and Littlefield Publishers, Inc.

Prasad, S., and Enzel, Y., 2006, Holocene paleoclimates of India. Quaternary Research, v. 66, pp. 442-453.

Prasad, S., Witt, A., Kienel, U., Dulski, P., Bauer, E., and Yancheva, G., 2009, The 8.2 ka event: Evidence for seasonal differences and the rate of climate change in western Europe. Global and Planetary Change, v. 67, pp. 218-226.

Prasad, S., Anoop, A., Riedel, N., Sarkar, S., Menzel, P., Basavaiah, N., Krishnan, R., Fuller, D., Plessen, B., Gaye, B., and Röhl, U., 2014, Prolonged monsoon droughts and links to Indo-Pacific warm pool: A Holocene record from Lonar Lake, central India. Earth and Planetary Science Letters, v. 391, pp. 171-182.

Rajeevan, M., Unnikrishnan, C.K., Bhate, J., Niranjan Kumar, K., and Sreekala, P.P., 2012, Northeast monsoon over India: variability and prediction. Meteorological Applications, v. 19, pp. 226-236.

Rao, S.N., 1977, Continuity and survival of Neolithic traditions in northeast India. Asian Perspectives, v. 20, pp. 191-205.

Rashid, H., England, E., Thompson, L., and Polyak, L., 2011, Late glacial to Holocene Indian summer monsoon variability based upon sediment. Terr. Atmos. Ocean. Sci, v. 22, pp. 215-228.

Rawat, S., Gupta, A.K., Sangode, S.J., Srivastava, P., and Nainwal, H.C., 2015, Late Pleistocene-Holocene vegetation and Indian summer monsoon record from the Lahaul, northwest Himalaya, India. Quaternary Science Reviews, v. 114, pp. 167-181.

Ruddiman, W.F., 2003, The anthropogenic greenhouse era began thousands of years ago. Clim Change, v. 61, pp. 261-293.

Ruddiman, W.F., Fuller, D.Q., Kutzbach, J.E., Tzedakis, P.C., Kaplan, J.O., Ellis, E.C., Vavrus, S.J., Roberts, C.N., Fyfe, R., He, F., and Lemmen, C., 2016, Late Holocene climate: Natural or anthropogenic? Reviews of Geophysics, v. 54, pp. 93-118.

Sandeep, K., Shankar, R., Warrier, A.K., Yadava, M.G., Ramesh, R., Jani, R.A., Weijian, Z., and Xuefeng, L., 2017, A multi-proxy lake sediment record of Indian summer monsoon variability during the Holocene in southern India. Palaeogeography, palaeoclimatology, palaeoecology, v. 476, pp. 1-14.

Sarkar, A., Mukherjee, A.D., Bera, M.K., Das, B., Juyal, N., Morthekai, P., Deshpande, R.D., Shinde, V.S., and Rao, L.S., 2016, Oxygen isotope in archaeological bioapatites from India: Implications to climate change and decline of Bronze Age Harappan civilization. Scientific reports, v. 6, pp. 26555.

Saxena, A., Prasad, V., and Singh, I.B., 2013, Holocene palaeoclimate reconstruction from the phytoliths of the lake-fill sequence of Ganga Plain. Current science, v. 104, pp.1054-1062.

Saxena, A., Trivedi, A., Chauhan, M.S., and Sharma, A., 2015, Holocene vegetation and climate change in Central Ganga Plain: a study based on multiproxy records from Chaudhary-Ka-Tal,
Raebareli District, Uttar Pradesh, India. Quaternary International, v. 371, pp. 164-174.

Saxena, A., and Trivedi, A., 2017, Pollen based vegetation and climate change records deduced from the lacustrine sediments of Kikar Tal (Lake), Central Ganga Plain, India. The Palaeobotanist, v. 66, pp. 37-46.

Shinde, V.S., and Deshpande, S.S., 2002a, Central Indian Chalcolithic. In: P.N. Peregrine and M. Ember (Eds.), Encyclopedia of Prehistory. South and Southwest Asia, Kulwer Academic Press, New York, v. 8 pp. 34-39.

Shinde, V., and Deshpande, S.S., 2002b, South Indian Chalcolithic. In: P.N. Peregrine and M. Ember (Eds.), Encyclopedia of Prehistory. South and Southwest Asia, Kulwer Academic Press, New York, v. 8, pp. 344-360.

Singh, G., Joshi, R.D., Chopra, S.K., and Singh, A.B., 1974, Late Quaternary history of vegetation and climate in the Rajasthan Desert, India. Philosophical Transactions of the Royal Society of London, v. 267, pp. 467-501.

Singh, G., Wasson, R.J., and Agrawal, D.P., 1990, Vegetational and seasonal climatic changes since the last full glacial in the Thar Desert, northwestern India. Review of Palaeobotany and Palynology, v. 64, pp. 351-358.

Singh, J., and Yadav, R.R., 2005, Spring precipitation variations over the western Himalaya, India, since AD 1731 as deduced from tree rings. Journal of Geophysical Research. Atmospheres, v. 110, pp. D01110.

Singh, U., 2008, A History of Ancient and Early Medieval India: From the Stone Age to the 12th Century. Pearson Education, India.

Singh, A., Thomsen, K.J., Sinha, R., Buylaert, J.P., Carter, A., Mark, D.F., Mason, P.J., Densmore, A.L., Murray, A.S., Jain, M. and Paul, D., 2017, Counter-intuitive influence of Himalayan river morphodynamics on Indus Civilisation urban settlements. Nature communications, v. 8, pp. 1617.

Singhvi, A.K., and Kale, V.S., 2010, Paleoclimate Studies in India: Last Ice Age to the Present. Indian Natl Sci Academy.

Singhvi, A.K., Rupakumar, K., Thamban, M., Gupta, A.K., Kale, V.S., Yadav, R.R., Bhattacharyya, A., Phadtare, N.R., Roy, P.D., Chauhan, M.S., and Chauhan, O.S., 2010, Instrumental, terrestrial and marine records of the climate of South Asia during the Holocene. In: Mitra A.P., Sharma C. (Eds), Global Environmental Changes in South Asia. Springer, Dordrecht, pp. 54-124.

Sinha, A., Berkelhammer, M., Stott, L., Mudelsee, M., Cheng, H., and Biswas, J., 2011, The leading mode of Indian Summer Monsoon precipitation variability during the last millennium. Geophysical Research Letters, v. 38, pp. L15703.

Sinha, A., Kathayat, G., Cheng, H., Breitenbach, S.F., Berkelhammer, M., Mudelsee, M., Biswas, J., and Edwards, R.L., 2015, Trends and oscillations in the Indian summer monsoon rainfall over the last two millennia. Nature communications, v. 6, pp. 7309.

Sreekala, P.P., Rao, S.V.B., and Rajeevan, M., 2012, Northeast monsoon rainfall variability over south peninsular India and its teleconnections. Theoretical and applied climatology, v. 108, pp. 73-83.

Srivastava, P., Bhakuni, S.S., Luirei, K., and Misra, D.K., 2009, Morpho sedimentary records at the Brahmaputra River exit, NE Himalaya: climate-tectonic interplay during the Late PleistoceneHolocene. Journal of Quaternary Science, v. 24, pp. 175-188.

Srivastava, P., Kumar, A., Mishra, A., Meena, N.K., Tripathi, J.K., Sundriyal, Y.P., Agnihotri, R. and Gupta, A.K., 2013, Early Holocene monsoonal fluctuations in the Garhwal higher Himalaya as inferred from multi-proxy data from the Malari paleolake. Quaternary Research, v. 80, pp.447-458.

Srivastava, P., Agnihotri, R., Sharma, D., Meena, N., Sundriyal, Y.P., Saxena, A., Bhushan, R., Sawlani, R., Banerji, U.S., Sharma, C. 
and Bisht, P., 2017, 8000-year monsoonal record from Himalaya revealing reinforcement of tropical and global climate systems since mid-Holocene. Scientific reports, v. 7(1), pp. 14515.

Srivastava, P., Pal, D.K., Aruche, K.M., Wani, S.P., and Sahrawat, K.L., 2015, Soils of the Indo-Gangetic Plains: a pedogenic response to landscape stability, climatic variability and anthropogenic activity during the Holocene. Earth-Science Reviews, v. 140, pp. 54-71.

Staubwasser, M., and Weiss, H., 2006, Holocene climate and cultural evolution in late prehistoric-early historic West Asia. Quaternary Research, v. 66, pp. 372-387.

Sun, D.Z., 2000, Global climate change and El Niño: A theoretical framework. El Nino and Southern Oscillation. Cambridge University Press, Cambridge, pp. 443-463.

Swain, A., Kutzbach, J.E., and Hastenrath, S., 1983, Estimates of Holocene precipitation for Rajasthan, India, based on pollen and lake-level data. Quaternary Research, v. 19, pp. 1-17.

Tiwari, M., Managave, S., Yadava, M.G., and Ramesh, R., 2009, Spatial and temporal coherence of paleomonsoon records from marine and land proxies in the Indian region during the past 30 ka. Current Science, pp. 517-537.

Tiwari, M., Singh, A.K., and Ramesh, R., 2011, High-resolution monsoon records since Last Glacial Maximum: a comparison of marine and terrestrial paleoarchives from South Asia. Journal of Geological Research, v. 2011, pp. 1-12.

Veena, M.P., Achyuthan, H., Eastoe, C., and Farooqui, A., 2014, A multi-proxy reconstruction of monsoon variability in the late Holocene, South India. Quaternary International, v. 325, pp. 63-73.

Vollweiler, N., Scholz, D., Mühlinghaus, C., Mangini, A., and Spötl, C., 2006, A precisely dated climate record for the last 9 kyr from three high alpine stalagmites, Spannagel Cave, Austria. Geophysical Research Letters, v. 33, pp. 1-5.

Walker, M., Head, M.J., Berkelhammer, M., Björck, S., Cheng, H., Cwynar, L., Fisher, D., Gkinis, V., Long, A., Lowe, J., Newnham, R., Rasmussen, S.O., and Weiss, H., 2018, Formal ratification of the subdivision of the Holocene Series / Epoch (Quaternary
System / Period ): two new Global Boundary Stratotype Sections and Points ( GSSPs ) and three new stages / subseries. Episode v. 41, pp. 213-223.

Walker, M.J., Berkelhammer, M., Björck, S., Cwynar, L.C., Fisher, D.A., Long, A.J., Lowe, J.J., Newnham, R.M., Rasmussen, S.O., and Weiss, H., 2012, Formal subdivision of the Holocene Series/ Epoch: a Discussion Paper by a Working Group of INTIMATE (Integration of ice core, marine and terrestrial records) and the Subcommission on Quaternary Stratigraphy (International Commission on Stratigraphy). Journal of Quaternary Science, v. 27, pp. 649-659.

Wasson, R.J., Smith, G.I., and Agrawal, D.P., 1984, Late Quaternary sediments, minerals, and inferred geochemical history of Didwana Lake, Thar Desert, India. Palaeogeography, Palaeoclimatology, Palaeoecology, v. 46, pp. 345-372.

Wedage, O., Amano, N., Langley, M.C., Douka, K., Blinkhorn, J., Crowther, A., Deraniyagala, S., Kourampas, N., Simpson, I., Perera, N., Picin, A., Boivin, N., Petraglia, M, Roberts, P., 2019, Specialized rainforest hunting by Homo sapiens $\sim 45,000$ years ago. Nature Communications, v. 10, pp. 739.

Wünnemann, B., Demske, D., Tarasov, P., Kotlia, B.S., Reinhardt, C., Bloemendal, J., Diekmann, B., Hartmann, K., Krois, J., Riedel, F., and Arya, N., 2010, Hydrological evolution during the last 15 kyr in the Tso Kar lake basin (Ladakh, India), derived from geomorphological, sedimentological and palynological records. Quaternary Science Reviews, v. 29, pp. 1138-1155.

Yadava, M.G., and Ramesh, R., 2005, Monsoon reconstruction from radiocarbon dated tropical Indian speleothems. The Holocene, v. 15, pp. 48-59.

Yadav, R. R., Gupta, A. K., and Kotlia, B. S., 2017, Recent Wetting and Glacier Expansion in the Northwest Himalaya and Karakoram. Scientific Report, v. 7, pp. 1-8. doi: 10.1038/s41598-017-063885.

Yasuda, Y., 2001, The Changing pulse of Monsoon and the rise and fall of the ancient civilizations in Eurasia. Monsoon and Civilization. In: Yasuda ,Y., and Shinde, V., Abstracts, (Ed.), Roli Books, New Delhi.

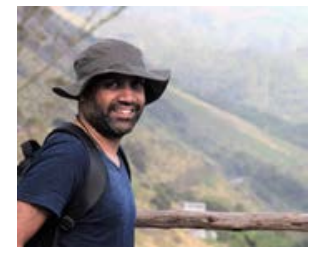

Dr. Ambili Anoop is currently working as an Assistant professor at Indian Institute of Science Education and Research (IISER) Mohali, India. His research interests lies in multi-proxy, multi-archive climate reconstruction, with special focus on developing transfer functions for quantification for palaeoclimate and understanding the impact of climate change on different components of the geo-ecosystem. He had utilized a combination of sedimentological (micro-facies), geochemical, isotopic and biomarker based proxies to decipher paleoenvironmental and paleo-vegetational changes.

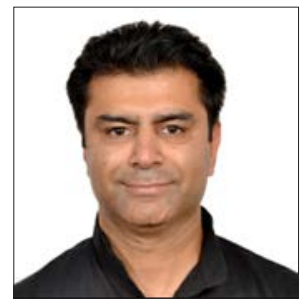

Dr. Parth R. Chauhan is a Faculty in the Department of Humanities and Social Sciences at Indian Institute of Science Education and Research, Mohali, Punjab. He completed his PhD from the University of Sheffield (UK) and specializes in the paleoanthropology of the Indian Subcontinent. He is currently working on Paleolithic and Mesolithic sites in central and western India through his own projects as well as through collaborations. He has also carried out field research in Yemen, Sudan and the USA.

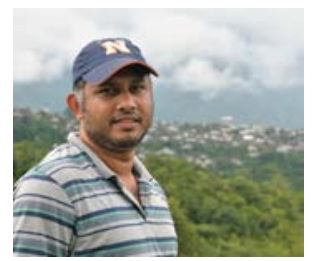

Dr. Praveen K. Mishra is working as a DST-INSPIRE Faculty at Wadia Institute of Himalayan Geology, Dehradun (India). His expertise lies in developing climate-proxy links, and palaeoclimate reconstruction using lake sediments. Currently, he is associated with several lake basin in India focussing on the reconstruction of past climate variability covering last two thousand years. 